PERM JOURNAL OF PETROLEUM AND MINING ENGINEERING

ВЕСТНИК ПНИПУ. ГЕОЛОГИЯ. НЕФТЕТАЗОВОЕ И ГОРНОЕ ДЕЛО

ISSN 2224-9923

Volume / Том 20 №1 2020

http://vestnik.pstu.ru/g

UDC 622.276:552.578.2.061.4

Article / Статья

(C) PNRPU / ПНИПУ, 2020

\title{
DEVELOPMENT ENGINEERING PRACTICE OF A FIELD WITH A SALINE RESERVOIR IN EASTERN SIBERIA. PART 2
}

\section{Saidabror B. Komalov, Andrey A. Maltsev, Georgy Yu. Shcherbakov ${ }^{1}$}

Saint Petersburg Mining University ( $22^{\text {st }}$ line, Vasilyevsky island, Saint Petersburg, 199106, Russian Federation)

${ }^{1}$ Gazpromneft NTC LLC (75-79, building D, Moika river embankment, Saint Petersburg, 190000, Russian Federation)

\section{ОПЫТ ПРОЕКТИРОВАНИЯ РАЗРАБОТКИ МЕСТОРОЖДЕНИЯ ВОСТОЧНОЙ СИБИРИ С ЗАСОЛОНЕННЫМ КОЛЛЕКТОРОМ. ЧАСТЬ 2}

\section{С.Б. Комалов, А.А. Мальцев, Г.Ю. Щербаков ${ }^{1}$}

Санкт-Петербургский горный университет (199106, Россия, г. Санкт-Петербург, Васильевский остров, 21-я линия, 2)

${ }^{1}$ ООО «Газпромнефть-НТЦ» (190000, Россия, г. Санкт-Петербург, набережная реки Мойки, 75-79, литера Д)

Received / Получена: 02.10.2019. Accepted / Принята: 10.01.2020. Published / Опубликована: 02.03.2020

Key words:

field development, HTR, saline reservoir, inorganic sediments, desalination simulation, well productivity calculation.

\begin{abstract}
Engineering practice of a field complicated by high level of uncertainty in geological structure, abnormal properties and composition of formation water, and presence of halite in pore space of the reservoir is described. Maintaining reservoir pressure is fundamental for ensuring target production levels, yet its implementation is not always a trivial task. The problem of a saline reservoir simulation has been studied on an East Siberian field with reservoir's high heterogeneity, low permeability, and salination. Practice of determining the optimal system of development using modern methods of simulation, analysis and calculation is considered. Multivariate calculations were conducted using a hydrodynamic model based on the probabilistic geological model. The methodology of selecting the basic variants of the geological model corresponding to the probability of 10, 50, and $90 \%$ was used subject to two factors: initial geological reserves and reservoir connectivity. Qualitative and quantitative estimations of changes in production wells productivity due to problems caused by organic and inorganic sedimentation in the bottomhole formation zone were performed. Formation water and mineral composition of the rock formation were analysed. These data were used to simulate the organic and inorganic sedimentation in the bottomhole formation zone due to changes in pressure and temperature during production and fluid injection into the formation. The simulation of solids build-up during fluid flow in the bottomhole formation zone allowed us to determine threshold values of well producing characteristics and bottomhole pressure levels, as well as dependencies of decrease in reservoir properties of the bottomhole formation zone on the amount of pumped fluid under the selected well operation parameters.
\end{abstract}

Приведен опыт проектирования месторождения, осложненного высоким уровнем неопределенности по геологическому строению, аномальными свойствами и составом пластовой воды, наличием галита в поровом пространстве коллектора. Поддержание пластового давления - одно из обязательных условий обеспечения планируемых уровней добычи, однако его реализация не всегда тривиальная задача. На месторождении Восточной Сибири с высокой неоднородностью коллектора, низкой проницаемостью и засолонением исследована проблема моделирования засолоненного коллектора. Рассмотрен опыт определения оптимальной системы разработки с использованием современных методов моделирования, анализа и расчетов. Были выполнены многовариативные расчеты с помощью гидродинамической модели, за основу которой взята вероятностная геологическая модель. Использована методика выбора основных вариантов геологической модели, соответствующей вероятности $10 ; 50$ и 90 \% с учетом двух факторов: начальных геологических запасов и связности коллектора. Проведена качественная и количественная оценка изменения продуктивности добывающих скважин вследствие осложнений, вызванных выпадением органических и неорганических осадков в призабойной зоне пласта. Выполнен анализ пластовой воды и минералогического состава горной породы. Эти данные были использованы при моделировании образования органических и неорганических отложений в призабойной зоне пласта вследствие изменения термобарических условий при добыче и закачке жидкости в пласт. Моделирование образования твердой фазы при фильтрации жидкости в призабойной зоне пласта позволило выявить пороговые значения эксплуатационных характеристик скважины и уровней забойного давления, а также зависимости ухудшения фильтрационно-емкостных свойств призабойной зоны пласта от количества прокаченной жидкости при выбранном режиме работы скважины.

Saidabror B. Komalov - PhD student at the Department of Reservoir Engineering (tel.: +007 99954928 10, email: komalov@me.com). The contact person for correspondance. Andrey A. Maltsev (Author ID in Scopus: 57211248436) - PhD student at the Department of Reservoir Engineering (tel.: +007 911 789 25 49, e-mail: Maltsev.pstbox@gmail.com). Georgy Yu. Shcherbakov - Head of the Direction (tel.: +007 8123136924 (3028)), e-mail: Shcherbakov.gu@gazpromneft-ntc.ru).

Комалов Саидаброр Бахтиярович - аспирант кафедры разработки и эксплуатации нефтяных и газовых месторождений (тел.: +00799954928 10 , e-mail: komalov@me.com). Контактное лицо для переписки.

Мальцев Андрей Андреевич - аспирант кафедры разработки и эксплуатации нефтяных и газовых месторождений (тел.: +007911 7892549 , e-mail: Maltsev.pstbox@gmail.com).

Щербаков Георгий Юрьевич - руководитель направления (тел.: +007 8123136924 (3028)), e-mail: Shcherbakov.gu@gazpromneft-ntc.ru). 


\section{Introduction}

The field under study is complicated by a high level of uncertainty in geological structure [1-3], abnormal properties and composition of formation water, and the presence of halite [4] in pore space of the reservoir.

Due to a combination of geological and physical properties (type of reservoir, low porosity and permeability, high compartmentalisation of formations), the hydrocarbon reserves of productive formations are hard to recover. The field is mainly characterised by:

- high reservoir compartmentalisation, block structure;

- low reservoir properties;

- low reservoir temperature;

- reservoir salination; and

- high formation water mineralisation.

The main productive area includes terrigenous deposits with average porosity values of $10 \%$, permeability from $1 \mathrm{mD}$ to $1 \mathrm{D}$, average value of $150 \mathrm{mD}$, net oil thicknesses of 8-10 m, on average. Due to the massive character of the deposit, significant net gas pay zones, under-gas-cap zones, net oil pay zones, and underlying water zones can be distinguished.

\section{Flow Model Building}

Numerical simulation model allows one to calculate the consequences of a certain engineering solution to a production problem using a computing experiment method. Creation of a live hydrodynamic model was aimed at addressing the problems of the optimal scenario of field development [5], including:

- study of the fluid flow processes in productive formations;

- determination of optimal parameters of the development system;

- study of possibilities to enhance the formation development;

- determination of optimal development scenario; and

- forecast of probable production volumes.

Oil reserves in the field are classified as hard-torecover, due to low permeability and high geological heterogeneity. This makes it necessary to artificially maintain formation pressure during reservoir operation from the very beginning of its development $[6,7]$. When water is injected into a reservoir, especially with low permeability, the oil displacement process is mostly affected by pore space structure, rock wettability, and swelling of clay minerals. Distinctive features of the reservoir under study include its salinity [8-10], as well as high mineralisation (400 g/l) and high viscosity $(4 \mathrm{cPz})$ of the formation water.

The overlying low-mineralised water is currently the agent of reservoir maintenance [11], which, when injected into the reservoir, will react with formation water, reducing its mineralisation, and also react with salt crystals, changing the pore space geometry. For the purpose of selecting the technology and agent of the formation pressure maintenance (FPM), a number of laboratory studies have been conducted using core samples and field fluids $[12,13]$. The laboratory studies have revealed that at injection of the flooding agent there is a significant change in the structure of the pore space, i.e. an increase in porosity, permeability, and connectivity of pore channels, etc. [10].

In multiphase numerical simulation models, the functions of relative permeabilities of a phase (RPF) play a significant role [14]. These functions are empirical and are determined in a laboratory environment on core samples, or analytically, using generalized dependencies. There are a number of factors affecting the RPF functions, including structural characteristic of the porous medium, wettability, direction of saturation variation, etc. However, the scope of laboratory research using core samples cannot be compared with that of the field, which is why the RPF functions and capillary pressures can be modified in the course of the model adaptation to the actual development data, as may be required.

RPF was modified [12] in order to allow for the influence of pore space salination at fresh water injection. The laboratory studies on desalination were reconstructed and the desalination model coefficients were obtained. Building a full-scale model with the chemical option of desalination is more timeconsuming and is not suitable for probabilistic calculations. To accelerate the calculations, the model was adapted using modified functions of relative permeability of a phase (MRPF) with regard to desalination. The results are presented in Fig. 1. As can be noted, a significant change in the water RPF curve is 
associated with an increase in permeability after desalination. It should be stated that the MRPF curves also allow for the change in formation water viscosity at the displacement front when fresh water is injected.

At the construction stage, geologic models were created that describe the existing reservoir uncertainties, from which it was necessary to choose three representative implementations to be used in the future. To address this problem, the calculations were performed applying GeoScreeening module which allows using streamlines to identify the most valid models with a probability of 10, 50 and $90 \%$ (hereinafter referred to as $p_{10}-p_{50}-p_{90}$ ) by reserves and subject to interconnected pore volume. Based on the calculation (Fig. 2), selected were the models that described three scenario cases: best-case, base-case and worst-case $\left(p_{10}-p_{50}-p_{90}\right.$, respectively).

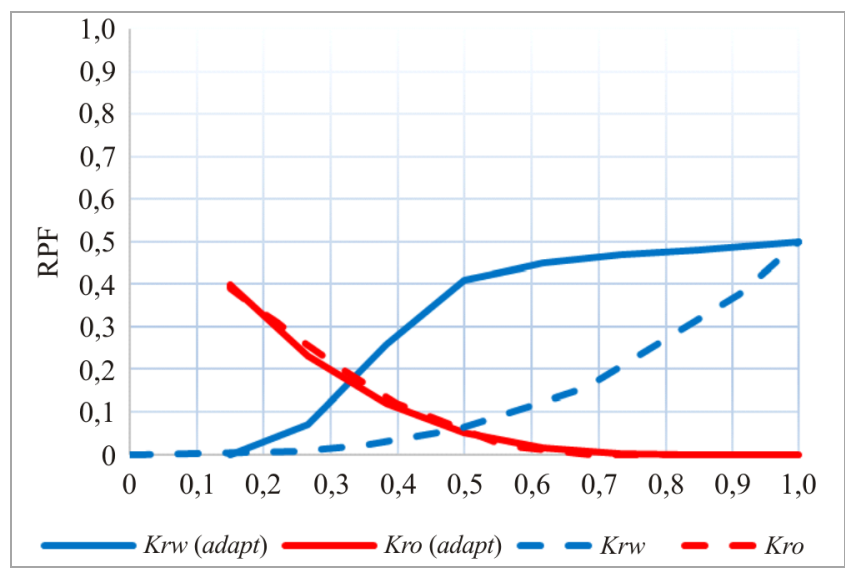

Fig. 1. Comparison of RPF values obtained from the laboratory core sample studies and MRPF values: $K r w$ and Kro are dependencies of relative permeability of a phase for water and oil, respectively (based on the core sample study) on the saturation of porous medium with water phase; Krw (adapt) and Kro (adapt) are modified dependencies of relative permeability of a phase for water and oil, respectively (based on the hydrodynamic model adaptation) on the saturation of porous medium with water phase

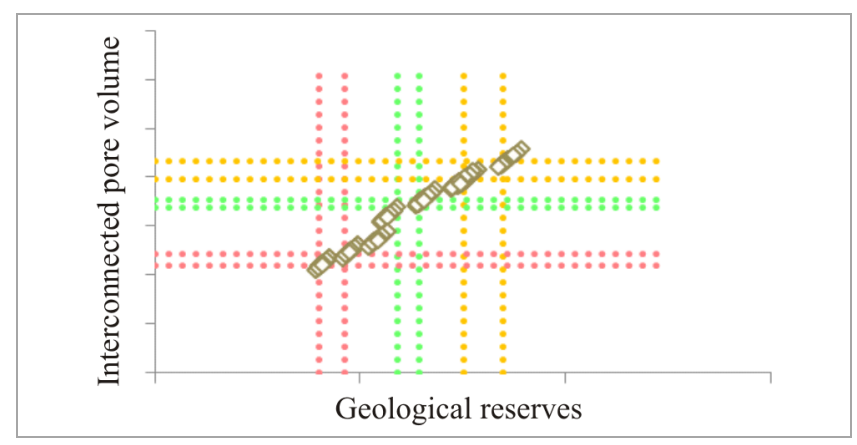

Fig. 2. Multi-parameter selection of three main scenarios of the geological model
The models differed in structure, distribution of flow properties (FP) and reservoir, and were limited by a significant spread in gas-oil and water-oil contact values. As a result, the difference in reserves between the worst-case and best-case scenario models is up to two times.

\section{Substantiation of Well Profiles}

A number of laboratory and computational studies were conducted to adjust for the risks of changes in production and injection wells performance in the process of field development.

Stage 1: collection and processing of information from laboratory studies [15] aimed at determining geological and physical characteristics of the reservoir:

- porosity, permeability and flow properties of the rock formation;

- mineralogical composition of the rock;

- mineralogical composition of formation water;

- component composition of oil;

- physical properties of formation fluids under reservoir conditions; and

- petrophysical dependencies.

Further, the results of special flow studies aimed at FPM agent selection were collected. The dependencies of permeability change on the amount of pumped pore volumes of water for various mineralisation and initial permeability were obtained in the course of laboratory studies, wherein it was accepted that the share of halite in the rock is proportional to its permeability. These dependencies were taken into account in multivariate calculations to select an effective FPM system.

Stage 2: qualitative analysis of permeability impairment risks in the bottomhole formation zone (BFZ) due to man-induced impact during production well operation. In addition to BFZ damage, occurring during a range of well operations (drilling, killing, hydraulic fracturing, well workover, etc.), there are risks of BFZ's flow properties impairment in the course of production and injection well operation [16-22]. The principal risk for production wells is organic and inorganic sedimentation, especially considering the abnormal mineralogical composition of rock and formation water, and pressure and temperature conditions of the deposit. 
For qualitative and quantitative prediction of organic sedimentation from oil (asphalteneresin-paraffin deposits (ARPD)) at the change of pressure and temperature conditions (simulation of the process of oil inflow to the well bottom), the initial data must be determined: pressure and temperature conditions, component composition of oil, molar mass of components, mass fraction of paraffins and asphaltenes in the oil composition, and molar mass of oil. Most of the data was obtained through laboratory tests of bottom-hole oil samples. Yet, to calculate the amount of settled asphaltenes, a more detailed component composition is necessary, rather than the one that is usually determined in standard studies. In the current situation, it was decided to use a component composition extension model. For this purpose, the $\mathrm{C} 7+$ fraction can be broken down into more components [22]. Next, the formation oil phase equilibrium under given pressure and temperature conditions was calculated based on the equation of state of the multi-component hydrocarbon system [23-32]. As a result, the dependencies of the settled ARPD volume ratio on temperature and pressure of the system were obtained (Fig. 3). Thus, it was established that at bottomhole pressure above $9 \mathrm{MPa}$, there is a minimal risk of ARPD sedimentation in BFZ. A large number of coefficients, taken by analogy, correlation method or from publications, were used in the course of calculations. An extended program of laboratory experiments to confirm the model applied is scheduled for the future.

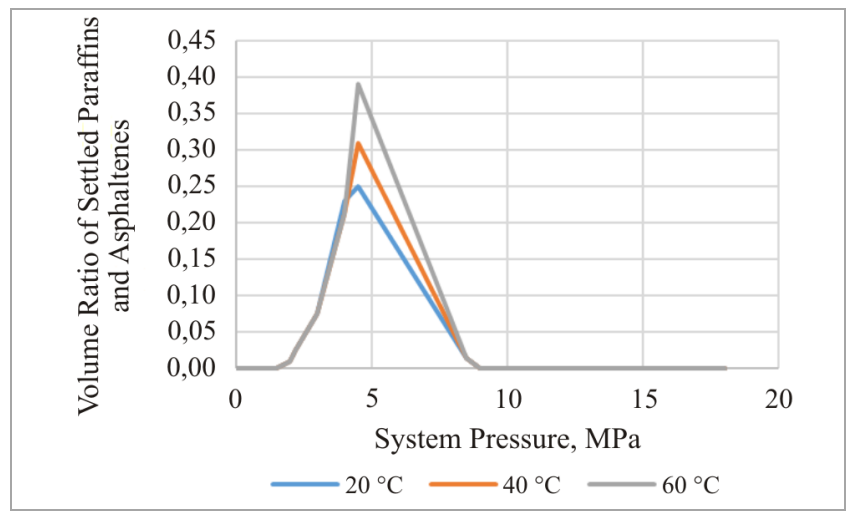

Fig. 3. Dependency of settled ARPD volume ratio on formation pressure
The model allowing for water phase flow and changes in the mass of rock and salt sedimentation was used [33, 34] for direct calculation of the probability of organic deposition and associated processes that affect flow properties. The qualitative model determines what happens to the salt component under current pressure and temperature conditions (depending on the thermodynamic resolution coefficient) [35]. The quantitative model is represented by a system of equations that was solved numerically using a difference scheme, where the first equation is the mass-conservation equation for salt, the second equation is the continuity equation for oil, the third equation is the continuity equation for water, and the fourth equation is the mass-conservation equation for rock (matrix).

$$
\left\{\begin{array}{c}
\frac{\partial \varepsilon \omega S \rho_{w}}{\partial t}+\operatorname{div} \rho_{w} \omega V_{w}=-\rho_{\text {salt }} \frac{\partial(1-\varepsilon)}{\partial t} \\
\frac{\partial \varepsilon(1-s)}{\partial t}+\operatorname{div} V_{o i l}=0, \\
\frac{\partial \varepsilon S(1-\omega) \rho_{w}}{\partial t}+\operatorname{div} \rho_{w}(1-\omega) V_{w}=0 \\
\rho_{\text {salt }} \frac{\partial(1-\varepsilon)}{\partial t}=-\rho_{w} \alpha S\left(\omega_{e q}-\omega\right) \omega,
\end{array}\right.
$$

where $\varepsilon$ is porosity, unit fractions; $\omega$ is dimensionless concentration of salt in water, unit fractions; $S$ is water saturation, unit fractions; $\alpha$ is mass-transfer coefficient, $1 / \mathrm{s} ; \rho_{w}, \rho_{\text {salt }}$ are densities of water and salt, respectively, $\mathrm{kg} / \mathrm{m}^{3}$; and $V_{w}, V_{\text {oil }}$ are flow rates of water and oil, respectively, $\mathrm{m} / \mathrm{s}$.

As a result, permeability profiles and share of salts settled in BFZ under the change of pressure and temperature conditions due to inflow to production well were obtained (Fig. 4). Anhydrite and a small share of calcite are the prevailing salts, formed in the $\mathrm{BFZ}$ according to all known data on the reservoir.

Distribution of the sediments and permeability ratio was calculated for different time periods, different flow properties and different modes of well operation (bottomhole pressure value and draw-down). The results were processed to obtain coefficients to the skin factor dependency on time using the Chirkov-Mikhailov's method [36]. The coefficients and dependencies were used in the hydrodynamic calculations. 


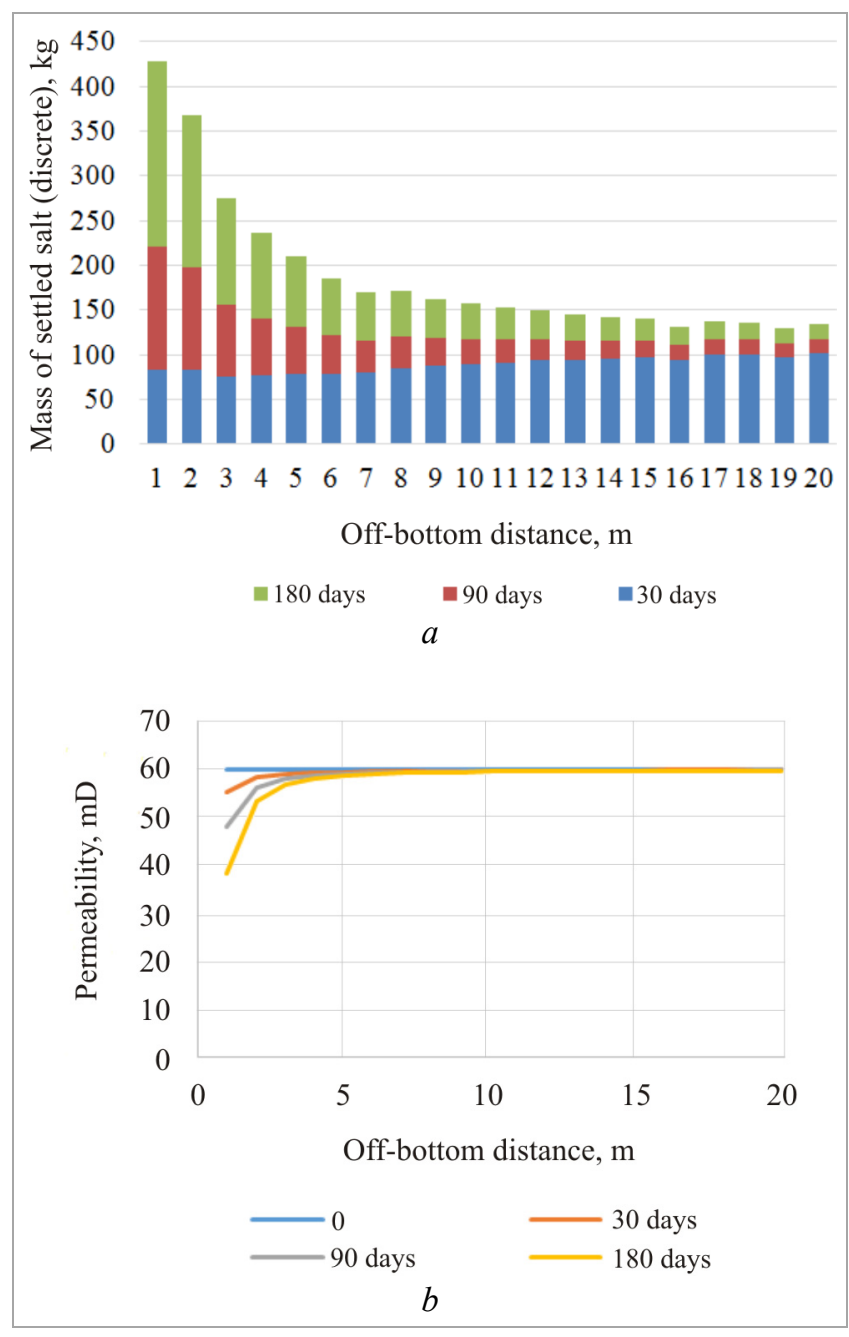

Fig. 4. Simulation of changes in flow properties of the production well BFZ during operation: distribution of inorganic sediment mass $(a)$ and permeability $(b)$ in BFZ

by results of various time intervals simulation

\section{Determination of Well Spacing Pattern}

The selection of effective development systems and optimal well-spacing pattern, which provide costeffective development, is based on both the practice of similar field development and the results of two- and three-dimensional mathematical simulation of the development process of the reservoir under study.

Authors of a number of researches have proved [37-40] that at a complex geology, in the conditions of heterogeneity of low- and medium-permeability reservoirs, the greatest productivity and high technical and economic performance are achieved through the use of dispersed injection system.

Nowadays, gas and oil reservoir development systems with horizontal wells (HW), which allow enhancing the development of hard-to-recover oil reserves where oil occurs between gas and water, are becoming more common [41-43]. In general, the accumulated field experience of HW operation implies that the horizontal well system is the most efficient and rational technology of field development for the conditions of reservoirs pertaining to the group under study. Yet, since horizontal wells can not provide a sufficient level of sweep efficiency per se due to the heterogeneity and discontinuity of the reservoir (Fig. 5), it was decided to use additional hydraulic fracturing (HF). Since the net oil pay zone is the priority area for development, the $\mathrm{HF}$ enables entering all stringers, thereby enhancing reserves recovery.

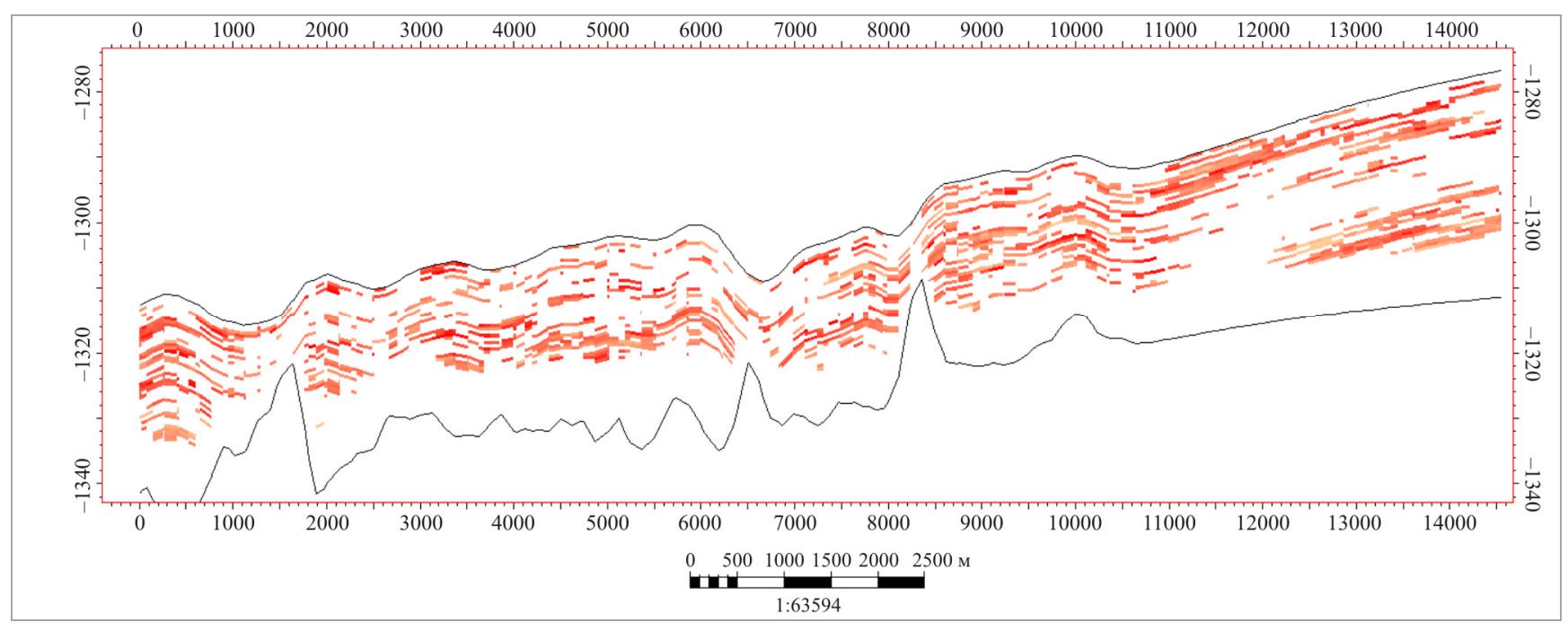

Fig. 5. East-to-west section of the geological model for the target reservoir 
The selection of the optimal development system was conducted subject to the following conditions: exploration maturity of the reservoir geology, formations' flow properties, physical and chemical characteristics of formation fluids, reservoir and well drive, the existing development system, the results of development analysis, the degree of depletion and the structure of remaining oil reserves, development background of deposits with similar characteristics, application of working agents for the implementation of the engineered system, maximum sweep efficiency, and effective drainage.

Since the geological structure and properties of the deposit productive formations are so far underresearched for commercial development of oil reserves, at this stage, a preliminary selection of the optimal reservoir development system is performed using a probabilistic geological model that includes several implementations.

For the previously selected implementations of the geological model $p_{10}-p_{50}-p_{90}$, the actual operation of existing wells was adapted to confirm their validity and the possibility of historical data recovery, prior to hydrodynamic calculations. The variants $\left(p_{10}-p_{50}-p_{90}\right)$ with different well spacing patterns were calculated with the adapted models (Fig. 6). The main parameters used to enhance the development system were narrowed down to enumeration of the indicators presented in the Table [44].

Comparison of indicators consisted in obtaining the cumulative production, but since this indicator does not always represent an economic and technological optimum, a simplified economic model was applied to adjust for the net present value (NPV) from the project implementation $[45,46]$ (Fig. 7).

Variable Parameters of the Optimal Development System Selection Model

\begin{tabular}{|l|c|c|c|c|}
\hline \multicolumn{1}{|c|}{ Parameter } & \multicolumn{4}{|c|}{ Variant } \\
\hline Well pattern & 5-spot & $\begin{array}{c}\text { Line- } \\
\text { drive }\end{array}$ & - & - \\
\hline Well pattern azimuth & $\begin{array}{c}\text { Along stress } \\
\text { trajectory }\end{array}$ & $\begin{array}{c}\text { Across } \\
\text { stress } \\
\text { trajectory }\end{array}$ & - & - \\
\hline $\begin{array}{l}\text { Well pattern area } \\
\text { (WPA), ha/well }\end{array}$ & 96 & 125 & 164 & 196 \\
\hline HW length, m & 1200 & 1400 & 1600 & \\
\hline Number of HF & 10 & 12 & 14 & \\
\hline $\begin{array}{l}\text { Flowback period of } \\
\text { injection wells, months }\end{array}$ & 1 & 2 & 4 & 6 \\
\hline
\end{tabular}

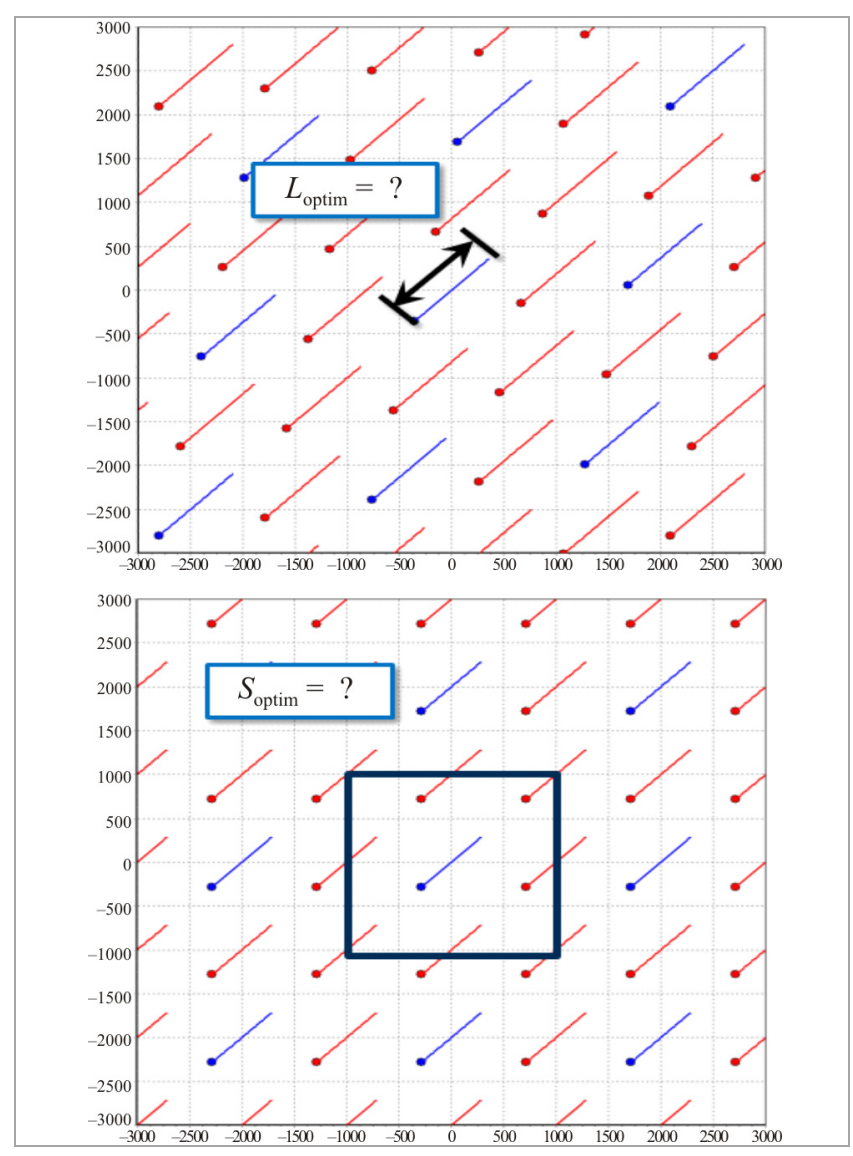

Fig. 6. Determination of the optimal length of horizontal wellbore section and the well pattern: $L_{\text {optim }}$ is optimal length of horizontal wellbore section entering the reservoir; $S_{\text {optim }}$ is optimal area per one well in the well pattern
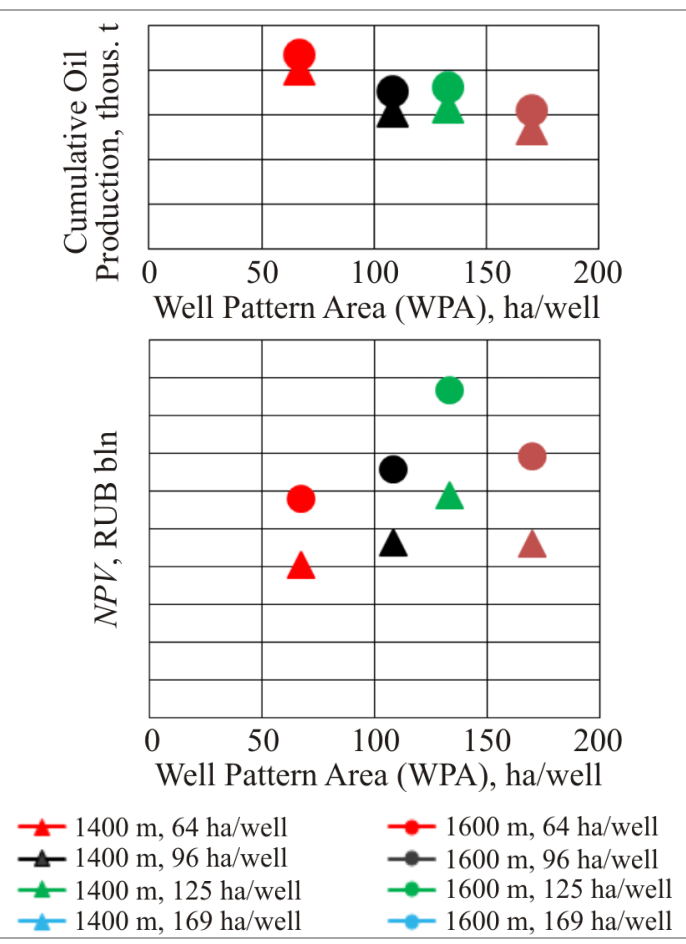

Fig. 7. Comparison of cumulative net production and NPV for well pattern variants with 1,400- and 1,600 m-long wells 


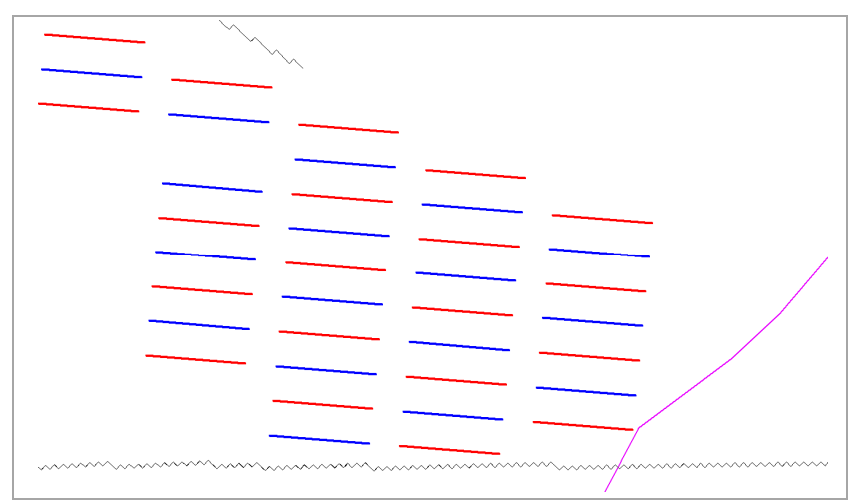

Fig. 8. Final variant of optimal well pattern

Graphical representation of the final system is given in Fig. 8: offset line drive pattern; horizontal wellbore length of $1,200 \mathrm{~m}$ with 14 stages of $\mathrm{HF}$, row spacing of $500 \mathrm{~m}$, and well spacing of $450 \mathrm{~m}$. The selected type of development system is relevant only for the pilot section of the deposit without a gas cap and underlying aquifers.

\section{Conclusion}

Besides the presence of halite in the pore space of the oil-saturated reservoir, the field under study is complicated by a number of other factors, from geology to abnormal properties of formation water. Following the conducted research and its consolidation involving comprehension of all the complicating factors, the laboratory and computational experiments aimed at finding an effective and economically-viable approach to the field development were carried out. Based on the information obtained in the course of laboratory research that involved geological and hydrodynamic simulation, probability calculations were performed, allowing for uncertainties at the current stage of the reservoir study. Geological and well exploitation risks were taken into account, and multivariate hydrodynamic calculations were performed. The most stable development system for the pilot area of the deposit was selected using the economic model.

\section{References}

1. Kiper V.N. Osobennosti stroeniia lovushek uglevodorodov $\mathrm{v}$ raionakh s razvitoi skladchatonadvigovoi tektonikoi na territorii deiatelnosti OAO "Surgutneftegaz" (Vostochnaia Sibir) [Structure features of hydrocarbon traps in the areas with developed folding and overthrust tectonics in the territory of Surgutneftegas OJSC (Eastern Siberia)]. Oil industry, 2018, no.1, pp.23-25.

2. Chirgun A., Levanov A., Gordeev Y., Lazeev A., Timchuk A. A case study of the Verkhnechonskoye field: theory and practice of Eastern Siberia complex reservoirs development. Society of Petroleum Engineers. DOI: 10.2118/189301-RU

3. Tye R.S., Hornbrook J.W., Prasse E.M., Robinson G.C., Lowe D.R., Morozov V.V. Appraisal of a precambrian oil and gas field: Verkhnechonskoye Field, East Siberia, Russian Federation (Russian). Society of Petroleum Engineers, 2008, January 1. DOI: $10.2118 / 116859-R U$

4. Nigamatov Sh.A., Ismagilova L.R., Boshchenko A.N. Prognozirovanie zon zasoloneniia peschanikov botuobinskogo gorizonta na primere
Chaiandinskogo mestorozhdeniia (Vostochnaia Sibir) [The prediction of salted zones of Botuobinskiy formation sandstone on the example of Chayandinskoye field (East Siberia)]. PRONEFT. Professionalno o nefti, 2019, no.3 (13), pp.35-40.

5. Cullick A.S., Narayanan K., Gorell S.B. Optimal field development planning of well locations with reservoir uncertainty. Society of Petroleum Engineers. DOI: 10.2118/96986-MS

6. Warner G.E. Waterflooding a highly stratified reservoir. Society of Petroleum Engineers. DOI: 10.2118/2106-PA

7. Phade A.A., Gupta Y. Reservoir pressure management using waterflooding: a case study. Society of Petroleum Engineers. DOI: $10.2118 / 113068-M S$

8. Antsiferov A.S. Metamorfizm rassolov i zasolonenie kollektorov nefti i gaza LennoTungusskoi neftegazonosnoi provintsii [Metamorphism of brines and salinization of oil and gas reservoirs of the Lenno-Tunguska oil and gas province]. Geologiia $i$ geofizika, pp.499-510. 
9. Vorobev V.S., Klinovaia Ia.S. Prichiny zasoloneniia terrigennykh porod $\mathrm{V}$ predelakh Verkhnechonskogo mestorozhdeniia (Vostochnaia Sibir) [Causes of salinization of terrifenous rock within the Verkhnechonskoe field (Eastern Siberia)]. Gazovaia promyshlennost, 2017, no. 4 (751), pp. 36-43.

10. Gaydukov L.A., Nikolaev V.A., Vorobev V.S. Features of water and process fluids effect on filtration properties of terrigenous reservoirs of the Nepa Suite of Eastern Siberia. Presented at SPE Russian Petroleum Technology Conference, 16-18 October. Moscow, 2017, pp.1-10. DOI: https://doi.org 10.2118/187880-MS

11. Morrow N., Buckley J. Improved oil recovery by low-salinity waterflooding. Society of Petroleum Engineers. DOI: 10.2118/129421-JPT

12. Komalov S., Shelest N. Solving the problems in the hydrodynamic modeling of the Eastern Siberia field with salted deposits. Presented at the SPE Russian Petroleum Technology Conference, Russia, 22-24 October 2019. Moscow, 2019, pp.1-14. DOI: $10.2118 / 196877-\mathrm{MS}$

13. Grinchenko V.A., Anuryev D.A., Miroshnichenko A.V., Gordeev Y.I., Lazeev A.N. Development history case of a major oil-gascondensate field in a new province. Society of Petroleum Engineers. DOI: 10.2118/166887-RU

14. Honarpour M., Mahmood S.M. Relativepermeability measurements: an overview. Society of Petroleum Engineers, pp.1-4. DOI: $10.2118 / 18565-\mathrm{PA}$

15. Gorodnov A.V., Chernoglazov V.N., Davydova O.P. Opredelenie filtratsionnoemkostnykh svoistv zasolonennykh kollektorov $\mathrm{v}$ terrigennykh otlozheniiakh nepskogo svoda Vostochnoi Sibiri [Determination of reservoir properties of salinized reservoirs in terrigenous sediments of the Nepal arch of Eastern Siberia]. Karotazhnik, 2012, 12 (22), pp.26-41.

16. Shcherbakov G., Yakovlev A., Groman A., Maltcev A. The development of chemical stimulation method trends in sandstone reservoirs. Presented at the SPE Russian Petroleum Technology Conference, Russia,
22-24 October 2019. Moscow, 2019, pp.1-7. DOI: https://doi.org/10.2118/196992-MS11

17. Ghalambor A., Economides M.J. Formation damage abatement: a quarter-century perspective. Paper SPE 58744 presented at the SPE International Symposium on Formation Damage. Lafaette, 2000.

18. Kononenko P., Skachedub D., Matsigorov A., Slidenko V., Listovshcik L. Antropogenic factors of near-wellbore zone colmatation and its' elimination. Neff Gaz. Novacii, 2012, no.7, pp.44-51.

19. Kononenko P., Skachedub A., Magadova L., Matsigorov A., Kozak P., Slidenko V., Listovshcik L. About some reasons of decrease or absence of acidizing effectiveness on production and injecting wells. Neft. Gaz. Novacii, 2012, no.12, pp.72-79.

20. Bilinchuk A.V., Khaliullin F.F., Sitnikov A.N. et al. Razrabotka i vnedrenie instrumenta dlia dostizheniia potentsiala dobychi [Automated solution to unlock base production potential]. Oil industry, 2016, no.12, pp.84-86.

21. Andzhukaev Ts.V., Margarit A.S., Pustovskikh A.A. A tool for achieving the base production potential. Paper SPE 187790-MS presented at SPE Russian Petroleum Technology Conference. Moscow, 2017.

22. Pedersen K.S., Christensen P.L. Phase behavior of petroleum reservoir fluids. Boca Raton, Taylor \& Francis Group, 2007.

23. Ahmed T. Equations of state and PVT analysis. Houston, Gulf Publishing Company, 2007, 570 p.

24. Chung F., Sarathi P., Jones R. Modeling of asphaltene and wax precipitation. Bartlesville: Bartlesville Project Office, 1991, p.47.

25. Firoozabadi A. Thermodynamics of hydrocarbon reservoirs. New York, McGrawHill Companies, 1999.

26. Hirshberg A. et al. Influence of temperature and pressure on asphaltene flocculation. Society of Petroleum Engineers Journal. New Orlean, 1984. SPE-11202-PA.

27. Isaeva A., Grushnikov I., Dobrozhanskiy V. Analysis of vapor-liquid equilibrium parameters of multicomponent hydrocarbon mixtures 
using cubic equations of state. SPE Russian Petroleum Technology Conference. Society of Petroleum Engineers. Moscow, 2018. SPE-191619-18RPTC-RU.

28. Lacerda D.B. et al. Evaluation of different correlation performance for the calculation of the critical properties and acentric factor of petroleum heavy fractions. Recent Insights in Petroleum Science and Engineering. Macaé, INTECH, 2017.

29. Nghiem L.X. et al. Efficient modeling of asphaltene precipitation. SPE Annual Technical Conference and Exhibition. Houston, Society of Petroleum Engineers, 1993. SPE-26642-MS.

30. Nghiem L.X., Aziz K., Li Y.K. A robust iterative method for flash calculations using the soave-redlich-kwong or the Peng-Robinson equation of state. Society of Petroleum Engineers Journal. Las Vegas, Society of Petroleum Engineers, 1983. SPE-8285-PA.

31. Vargas F.M., Tavakkoli M. Asphaltene deposition: fundamentals, prediction, prevention, and remediation. Boca Raton, Taylor \& Francis Group, 2018.

32. Won K.W. Thermodynamics for solid solution-liquid-vapor equilibria: wax phase formation from heavy hydrocarbon mixtures. Fluid phase equilibria. Amsterdam, Elsevier Science Publishers B.V., 1986, pp.265-279.

33. Segev R., Hasson D., Semiat R. Rigorous modeling of the kinetics of calcium carbonate deposit formation. AIChE Journal, 2011, 58(4), pp.1222-1229.

34. Calcium carbonate scale deposition kinetics on stainless steel surfaces, Omoregbe Bello. The University of Leeds School of Mechanical Engineering Leeds, 2017.

35. Laouafa F., Guo J., Quintard M., Luo H. Numerical modelling of salt leachingdissolution process. Presented at the 49th U.S. Rock Mechanics-Geomechanics Symposium, 28 June - 1 July, 2015. San Francisco, 2015, pp.1-10, available at: https://www.onepetro.org/ conference-paper/ARMA-2015-026 (accessed 12 September 2019).

36. Mikhailov H.H., Chirkov M.B. Obobshchennaia model kinetiki porazheniia plasta $\mathrm{v}$ protsesse razrabotki zalezhi [The generalized model of formation damage kinetics during field development]. Burenie $i$ neft, 2009, no.2, pp.32-33

37. Khasanov M.M., Ushmaev O.S., Nekhaev S.A., Karamutdinova D.M. Optimalnye parametry razrabotki neftianogo mestorozhdeniia [Optimal oil reservoir engineering parameters]. Rossiiskaia neftegazovaia tekhnicheskaia konferentsiia, 16-18 October 2012. Moscow, 2012, pp.1-21, available at: https://doi.org/10.2118/162089-RU (accessed 12 September 2019).

38. Belonogov E.V., Pustovskikh A.A., Samolovov D.A., Sitnikov A.N. Opredelenie kriteriev vybora optimalnogo sposoba razrabotki v nizkopronitsaemykh kollektorakh [Methodology for determination of low-permeability reservoirs optimal development plan]. Rossiiskaia neftegazovaia tekhnicheskaia konferentsiia, 24-26 October 2016. Moscow, 2016, pp.1-11, available at: https://doi.org/10.2118/182041-RU (accessed 12 September 2019).

39. Halvorsen G., Sagen J. A multiple fractured-horizontal well case study. Society of Petroleum Engineers, 2000, January 1. DOI: 10.2118/65503-MS

40. Wang B., Markitell B.N., Huang W.S. Case studies of horizontal well design and production forecast. Society of Petroleum Engineers,1993, January 1. DOI: 10.2118/25567-MS

41. Kovalchuk S.V., Polushina E.V., Gorenkova E.A. Results of studying and realization examples of oil rims fields development in the Gazpromneft company. PRONEFT. Professional'no o nefti, 2019, no.1(11), pp.12-17.

42. Samsundar K., Moosai R.S., Chung R.A. Effective reservoir management of thin oil rims. Society of Petroleum Engineers, 2005, January 1. DOI: $10.2118 / 94803-M S$

43. Cosmo C., Fatoke O. Challenges of gas development: Soku field oil rim reservoirs. Society of Petroleum Engineers, 2004, January 1. DOI: $10.2118 / 88894-M S$

44. Hazlett R.D., Babu D.K. Optimal well placement in heterogeneous reservoirs via semianalytic modeling. SPEJ, 2005, Sept, pp.286-296.

45. Sitnikov A.N., Pustovskikh A.A., Roshchektaev A.P., Andzhukaev T.V. A method to 
determine optimal switching time to injection mode for field development system. Oil industry, 2015, no.3, pp.84-87.
46. Brundred L.L. Economics of water flooding. Society of Petroleum Engineers, 1955, January 1. DOI: 10.2118/459-G

\section{Библиографический список}

1. Киперь В.Н. Особенности строения ловушек углеводородов в районах с развитой складчато-надвиговой тектоникой на территории деятельности ОАО «Сургутнефтегаз» (Восточная Сибирь) // Нефтяное хозяйство. - 2018. - № 1. - С. 23-25.

2. A case study of the Verkhnechonskoye field: theory and practice of Eastern Siberia complex reservoirs development / A. Chirgun, A. Levanov, Y. Gordeev, A. Lazeev, A. Timchuk // Society of Petroleum Engineers. DOI: $10.2118 / 189301-R U$

3. Appraisal of a precambrian oil and gas field: Verkhnechonskoye Field, East Siberia, Russian Federation (Russian) / R.S. Tye, J.W. Hornbrook, E.M. Prasse, G.C. Robinson, D.R. Lowe, V.V. Morozov // Society of Petroleum Engineers. 2008. - January 1. DOI: 10.2118/116859-RU

4. Нигаматов Ш.А., Исмагилова Л.Р., Бощенко А.Н. Прогнозирование зон засолонения песчаников ботуобинского горизонта на примере Чаяндинского месторождения (Bосточная Сибирь) // РROНЕФТЬ. Профессионально о нефти. - 2019. - № 3 (13). - С. 35-40.

5. Cullick A.S., Narayanan K., Gorell S.B. Optimal field development planning of well locations with reservoir uncertainty // Society of Petroleum Engineers. DOI: 10.2118/96986-MS

6. Warner G.E. Waterflooding a highly stratified reservoir // Society of Petroleum Engineers. DOI: 10.2118/2106-PA

7. Phade A.A., Gupta Y. Reservoir pressure management using waterflooding: a case study // Society of Petroleum Engineers. DOI: 10.2118/113068-MS

8. Анциферов А.С. Метаморфизм рассолов и засолонение коллекторов нефти и газа ЛенноТунгусской нефтегазоносной провинции. [Б.м.]: Геология и геофизика. - С. 499-510.

9. Воробьев В.С., Клиновая Я.С. Причины засолонения терригенных пород в пределах Верхнечонского месторождения (Восточная
Сибирь) // Газовая промышленность. - 2017. № 4 (751). - С. 36-43.

10. Gaydukov L.A., Nikolaev V.A., Vorobev V.S. Features of water and process fluids effect on filtration properties of terrigenous reservoirs of the Nepa Suite of Eastern Siberia // Presented at SPE Russian Petroleum Technology Conference, 16-18 October. - Moscow, 2017. P. 1-10. DOI: https://doi.org 10.2118/187880-MS

11. Morrow N., Buckley J. Improved oil recovery by low-salinity waterflooding // Society of Petroleum Engineers. DOI: 10.2118/129421-JPT

12. Komalov S., Shelest N. Solving the problems in the hydrodynamic modeling of the Eastern Siberia field with salted deposits // Presented at the SPE Russian Petroleum Technology Conference, Russia, 22-24 October 2019. - Moscow, 2019. - P. 1-14. DOI: 10.2118/196877-MS

13. Development history case of a major oilgas-condensate field in a new province / V.A. Grinchenko, D.A. Anuryev, A.V. Miroshnichenko, Y.I. Gordeev, A.N. Lazeev // Society of Petroleum Engineers. DOI: 10.2118/166887-RU

14. Honarpour M., Mahmood S.M. Relative-permeability measurements: an overview // Society of Petroleum Engineers. - P. 1-4. DOI: 10.2118/18565-PA

15. Городнов А.В., Черноглазов В.Н., Давыдова О.П. Определение фильтрационноемкостных свойств засолоненных коллекторов в терригенных отложениях непского свода Восточной Сибири // Каротажник. - 2012.12 (22). - C. 26-41.

16. The development of chemical stimulation method trends in sandstone reservoirs / G. Shcherbakov, A. Yakovlev, A. Groman, A. Maltcev // Presented at the SPE Russian Petroleum Technology Conference, Russia, 22-24 October 2019. Moscow, 2019. P. 1-7. DOI: https://doi.org/10.2118/196992-MS11

17. Ghalambor A., Economides M.J. Formation damage abatement: a quarter-century 
perspective // Paper SPE 58744 presented at the SPE International Symposium on Formation Damage. - Lafaette, 2000. - P. 1-15.

18. Antropogenic factors of near-wellbore zone colmatation and its' elimination / P. Kononenko, D. Skachedub, A. Matsigorov, V. Slidenko, L. Listovshcik // Neff Gaz. Novacii. - 2012. № 7. - P. 44-51.

19. About some reasons of decrease or absence of acidizing effectiveness on production and injecting wells / P. Kononenko, A. Skachedub, L. Magadova, A. Matsigorov, P. Kozak, V. Slidenko, L. Listovshcik // Neft. Gaz. Novacii. - 2012. - № 12. - P. 72-79.

20. Разработка и внедрение инструмента для достижения потенциала добычи / А.В. Билинчук, Ф.Ф. Халиуллин, А.Н. Ситников [и др.] // Нефтяное хозяйство. - 2016. - № 12. C. $84-86$.

21. Andzhukaev Ts.V., Margarit A.S., Pustovskikh A.A. A tool for achieving the base production potential // Paper SPE 187790-MS presented at SPE Russian Petroleum Technology Conference. - Moscow, 2017. - P. 1-15.

22. Pedersen K.S., Christensen P.L. Phase behavior of petroleum reservoir fluids. - Boca Raton: Taylor \& Francis Group, 2007. - P. 336.

23. Ahmed T. Equations of state and PVT analysis. - Houston: Gulf Publishing Company, 2007. $-570 \mathrm{p}$.

24. Chung F., Sarathi P., Jones R. Modeling of asphaltene and wax precipitation.Bartlesville: Bartlesville Project Office, 1991. P. 47.

25. Firoozabadi A. Thermodynamics of hydrocarbon reservoirs. - New York: McGrawHill Companies, 1999. - P. 335.

26. Influence of temperature and pressure on asphaltene flocculation / A. Hirshberg [et al.] // Society of Petroleum Engineers Journal. New Orlean, 1984. SPE-11202-PA.

27. Isaeva A., Grushnikov I., Dobrozhanskiy V. Analysis of vapor-liquid equilibrium parameters of multicomponent hydrocarbon mixtures using cubic equations of state // SPE Russian Petroleum Technology Conference / Society of Petroleum Engineers. - Moscow, 2018. SPE-191619-18RPTC-RU.
28. Evaluation of different correlation performance for the calculation of the critical properties and acentric factor of petroleum heavy fractions / D.B. Lacerda [et al.] // Recent Insights in Petroleum Science and Engineering. - Macaé: INTECH, 2017. - P. 160.

29. Efficient modelling of asphaltene precipitation / L.X. Nghiem [et al.] // SPE Annual Technical Conference and Exhibition.Houston: Society of Petroleum Engineers, 1993. SPE-26642-MS.

30. Nghiem L.X., Aziz K., Li Y.K. A robust iterative method for flash calculations using the soave-redlich-kwong or the Peng-Robinson equation of state // Society of Petroleum Engineers Journal. - Las Vegas: Society of Petroleum Engineers, 1983. SPE-8285-PA.

31. Vargas F.M., Tavakkoli M. Asphaltene deposition: fundamentals, prediction, prevention, and remediation. - Boca Raton: Taylor \& Francis Group, 2018. - P. 381.

32. Won K.W. Thermodynamics for solid solution-liquid-vapor equilibria: wax phase formation from heavy hydrocarbon mixtures // Fluid Phase Equilibria. - Amsterdam: Elsevier Science Publishers B.V., 1986. C. 265-279.

33. Segev R., Hasson D., Semiat R. Rigorous modeling of the kinetics of calcium carbonate deposit formation // AIChE Journal. - 2011. 58(4). - P. 1222-1229.

34. Omoregbe Bello. Calcium carbonate scale deposition kinetics on stainless steel surfaces, / The University of Leeds School of Mechanical Engineering Leeds, UK, 2017. - P. 218.

35. Numerical modelling of salt leachingdissolution process / F. Laouafa, J. Guo, M. Quintard, H. Luo // Presented at the 49th U.S. Rock Mechanics-Geomechanics Symposium, 28 June - 1 July, 2015. - San Francisco, 2015. P. 1-10. URL: https://www.onepetro.org/conferencepaper/ARMA-2015-026 (дата обращения: 12.09.2019).

36. Михайлов Н.Н., Чирков М.В. Обобщенная модель кинетики поражения пласта в процессе разработки залежи // Бурение и нефть. 2009. - № 2. - C. 32-33 
37. Оптимальные параметры разработки нефтяного месторождения / М.M. Хасанов, О.С. Ушмаев, С.А. Нехаев, Д.М. Карамутдинова // Российская нефтегазовая техническая конференция, 16-18 октября 2012 г. - М., 2012. C. 1-21. - URL: https://doi.org/10.2118/162089-RU (дата обращения: 12.09.2019).

38. Определение критериев выбора оптимального способа разработки в низкопроницаемых коллекторах [Электронный peсурс] / Е.В. Белоногов, А.А. Пустовских, Д.А.Самоловов, А.Н. Ситников // Российская нефтегазовая техническая конференция, 24-26 октября 2016 г. - Москва, 2016. C. 1-11. - URL: https://doi.org/ 10.2118/182041-RU (дата обращения: 12.09.2019).

39. Halvorsen G., Sagen J. A multiple fractured-horizontal well case study // Society of Petroleum Engineers. - 2000. - January 1. DOI: $10.2118 / 65503-\mathrm{MS}$

40. Wang B., Markitell B.N., Huang W.S. Case studies of horizontal well design and production forecast // Society of Petroleum Engineers. - 1993. - January 1. DOI: $10.2118 / 25567-M S$
41. Kovalchuk S.V., Polushina E.V., Gorenkova E.A. Results of studying and realization examples of oil rims fields development in the Gazpromneft company // PRONEFT. Professional'no o nefti. - 2019. - № 1 (11). - P. 12-17.

42. Samsundar K., Moosai R.S., Chung R.A. Effective reservoir management of thin oil rims // Society of Petroleum Engineers. - 2005. - January 1. DOI: 10.2118/94803-MS

43. Cosmo C., Fatoke O. Challenges of gas development: Soku field oil rim reservoirs // Society of Petroleum Engineers. - 2004. - January 1. DOI: 10.2118/88894-MS

44. Hazlett R.D., Babu D.K. Optimal well placement in heterogeneous reservoirs via semianalytic modeling // SPEJ. - 2005. - Sept. P. 286-296.

45. A method to determine optimal switching time to injection mode for field development system / A.N. Sitnikov, A.A. Pustovskikh, A.P. Roshchektaev, T.V. Andzhukaev // Oil industry. - 2015. - № 3. - P. 84-87.

46. Brundred L.L. Economics of water flooding // Society of Petroleum Engineers. 1955. - January 1. DOI: 10.2118/459-G

Please cite this article in English as:

Komalov S.B., Maltsev A.A., Shcherbakov G.Yu. Development engineering practice of a field with a saline reservoir in Eastern Siberia. Part 2. Perm Journal of Petroleum and Mining Engineering, 2020, vol.20, no.1, pp.60-71. DOI: $10.15593 / 2224-9923 / 2020.1 .6$

Просьба ссылаться на эту статью в русскоязычных источниках следующим образом:

Комалов С.Б., Мальцев А.А., Щербаков Г.Ю. Опыт проектирования разработки месторождения Восточной Сибири с засолоненным коллектором. Часть 2 // Вестник Пермского национального исследовательского политехнического университета. Геология. Нефтегазовое и горное дело. - 2020. - Т.20, №1. - C.60-71. DOI: 10.15593/2224-9923/2020.1.6 